\title{
THE INFLUENCE OF HUMAN RESOURCE MANAGEMENT PRACTICES AND JOB INVOLVEMENT ON THE EMPLOYEE PERFORMANCE IN THE PUBLIC SERVICE SECTORS MEDIATED BY AFFECTIVE COMMITMENT
}

\author{
Verlina Dwi Pamungkas \\ Faculty of Islamic Economics and Business, IAIN Surakarta, Indonesia \\ verlinadwipamungkas99@gmail.com \\ Fitri Wulandari \\ Faculty of Islamic Economics and Business, IAIN Surakarta, Indonesia \\ fitri.wulandari@iain-surakarta.ac.id
}

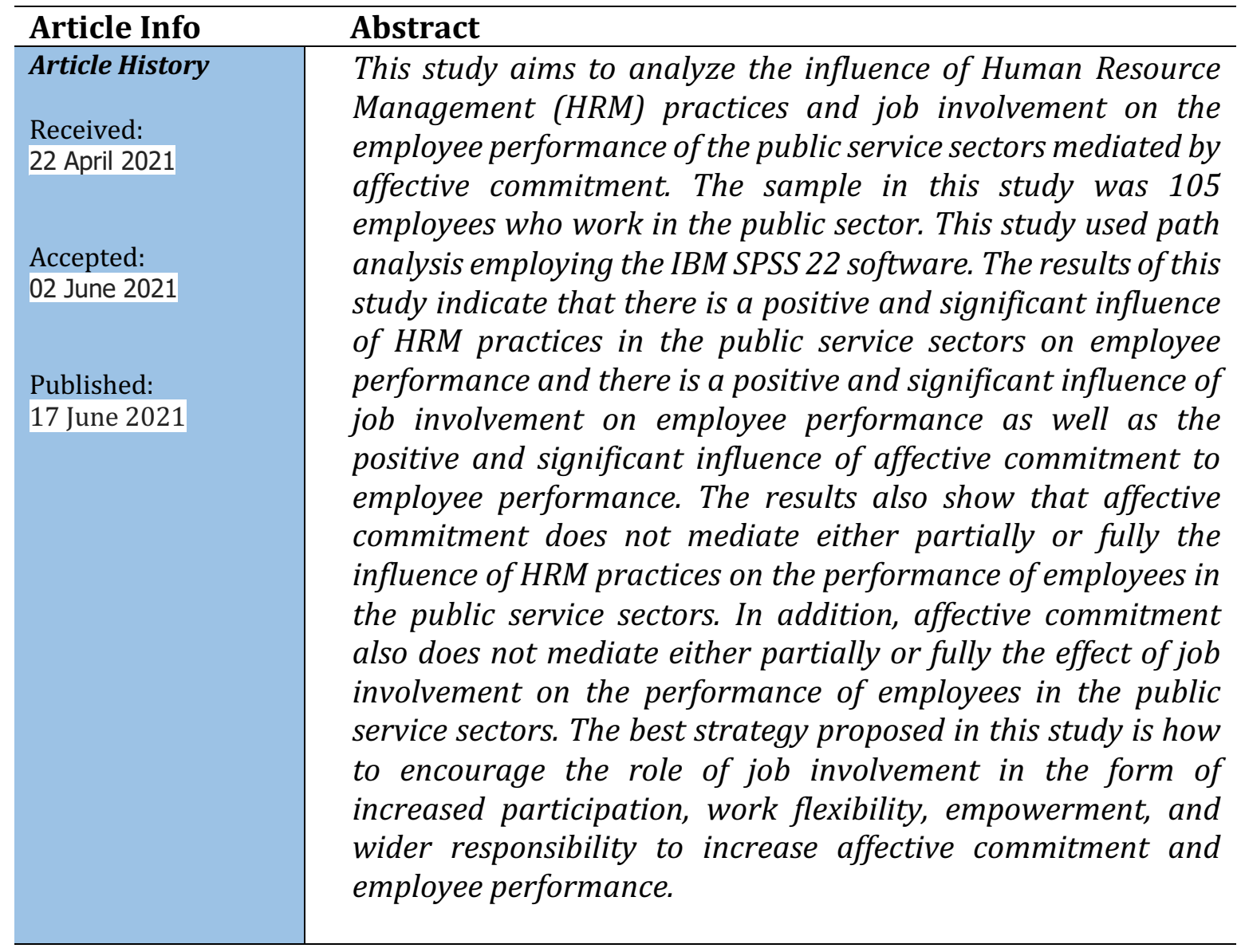

Keywords: HRM Practices, Job involvement, Employee Performance, Affective Commitment

\section{INTRODUCTION}

Public services are activities provided to the community acting to meet the needs of public services, goods, and administrative services. Public services are regulated in Law no. 25 of 2009 concerning public services. In this law, state is obliged to serve every citizen in fulfilling their basic 
rights and needs in the framework of public services. Therefore, human resources for providing public services play an important role to carry out business activities during the COVID-19 pandemic.

The important role of human resources refers to the employee performance in carrying out tasks to achieve company goals during the current Covid-19 pandemic as well as in the future. The success achieved by employees can be measured through the standards set by the company. To achieve this, HRM practices are needed. HRM practices are the use of human resources to achieve organizational goals. HRM practices are related to selection procedures, training, performance appraisals, rewards, and job security that can help achieve company goals and increase organizational commitment (Kitchot et al., 2020; Mardatillah et al., 2013). HRM practices are used to manage human resources in an organization to create a competitive advantage for organizational goals (Kamuri, 2017). HRM practices also affect employees' perceptions of how much the company pays attention to their well-being; they perceive what they have given to the organization will be rewarded through HRM policies (Tri Wikaningrum, 2011).

Job involvement is employee participation in the firm, both physically and non-physically as well as caring about a job in terms of knowledge and emotions (Rotenberry \& Moberg, 2007). Employees are said to be emotionally involved if they feel that they are important members in an organization. Hence, they will devote all their knowledge and abilities to achieve organizational goals. Job involvement is how much an individual's psychological identification with his job is. The greater the individual identifies with his work, the higher the employee's job involvement. If employees have a high commitment to the organization and are fully involved with work duties and responsibilities, they will try to achieve maximum results for their duties and responsibilities.

HRM practices are strategies of how organizations utilize their resources to achieve business excellence (Rotenberry \& Moberg, 2007). Various studies have shown that HRM practices increase employee engagement as well as employee performance (Delery \& Gupta, 2016; DiazFernandez et al., 2017; Moideenkutty et al., 2011). Several studies explain that there is a significant positive relationship of training and employee commitment to employee performance (Ocen et al., 2017). Affective commitment is the emotional attachment that employees have to the organization (Wulandari \& Putriyanti, 2020). If individuals or employees have a strong bond to the organization, they will be cohesive and get pleasure since they have become members of the organization (Wulandari et al., 2018). Affective commitment is multidimensional in nature, which involves employee loyalty to the organization as well as employee willingness to exert effort on behalf of the organization, with the goals and conformity to the organization (Muma et al., 2014). Employees with high affective commitment meet the demands of work, have a strong loyalty to 
the organization, and have a low intensity of turnover. Therefore, the purpose of this research is to provide information and input to the public service sectors, in terms of policy, references, and scientific development in improving the performance of employees working in the public service sectors during the COVID-19 pandemic.

\section{LITERATURE REVIEW AND HYPOTHESIS DEVELOPMENT HRM Practices}

HRM practices are a process of attracting, developing, and maintaining a talented and energetic workforce to support an organization's mission, goals, and strategies. In addition to improving skills, HRM practices also motivate employees to pursue opportunities as the source of organizational excellence (Delery \& Gupta, 2016). Retaining valuable employees is one of the strategic steps for organizations to survive and thrive in the global market and in times of crisis today. HRM practices refer to policies that are carried out consistently and internally, designed, and implemented to ensure that the company's human resources contribute to the achievement of organizational goals (Memon et al., 2020). Generally, HRM practices are used by organizations to attract, motivate, reward, and retain employees in the organization (Kitchot et al., 2020).

The main purpose of HRM practices is none other than to improve employee performance. When employees feel they are treated well in their organization through HRM practices, they will devote optimal efforts and energy to improve service quality. Effective use of human resources can provide a competitive advantage to the organization (Nasurdin et al., 2015). In line with Nasurdin et al., (2015), HRM practices consist of four different practices. The first is selective recruitment, which is a number of activities that are carefully matched between job applicants with job requirements to find workers with the best talents and offer appropriate compensation to maintain them in the organization. The right placement can be ensured since it matches the nature and knowledge possessed. Second, communication is one of the easy ways to encourage employee involvement because communication can improve teamwork, job satisfaction, and commitment. Third, assessment is the process of assessing the results of employee performance on the determined standards set by the organization in achieving goals. Fourth, an award is an appreciation and recognition from the organization to its employees to motivate employees to achieve the values and goals of the organization. It is reinforced by Kitchot et al., (2020) that HRM practices include the process of recruiting, evaluating, awarding, and retaining employees as well as providing benefits, health, and security. In principle, HRM practice is very important for all organizations to improve agility, commitment, and performance. 


\section{Job involvement}

Job involvement encourages a person to participate in self-development and motivation making it a long-term investment (Zhang et al., 2020). Job involvement is reflected in the employee's strong self-image and self-esteem that shows their identity. Their self-esteem by considering work as very important as well as self-image shows who they are with a positive image (Hermawati \& Mas, 2017). In line with Rotenberry \& Moberg (2007), job involvement is the extent to which an individual is known in his work, how much he actively participates in it and considers work as very important in his life. Two characteristics of job involvement need to be considered in the company. First, job involvement must refer to the psychological relationship with work assignments rather than attitudes towards the organization. Second, job involvement concerning self-investment, which is a personal resource in work (Muma et al., 2014).

Panjaitan (2018) describes the nature of employee involvement and participation includes mental and emotional involvement. It is not just the physical activity requested but also the mental and emotional involvement of the employee. This is proven by the development of employee positive thinking that makes them perform optimally in the workplace. In addition, employees' emotional involvement can be shown based on the level of employee motivation by doing work regularly, participating regularly, and being involved in decision-making (Zhang et al., 2020). The involvement and participation of employees do not only cover its essence but also include aspects that affect employee involvement and participation in the organization. Panjaitan (2018) adds that the view that employee engagement includes cognitive aspects, focusing on employees who have confidence in the company and the work. The emotional aspect that involvement relates to the feelings and behavior of employees towards the company and work. The behavioral aspect aims to see how employees process time in completing work, thinking skills, or energy used in completing work.

\section{Affective Commitment}

Organizational commitment is an attachment between employees and the organization. Supported by Şendoğdu et al. (2013), organizational commitment is a psychological relationship between organizational goals and employee goals that play a role in improving operational performance such as increased work quality, low costs, or intangible performance measures. According to Paolillo et al. (2015), organizational commitment is considered as one of the most important factors that support employee engagement for change initiatives.

Commitment can be observed from three dimensions of cognitive, emotional, and behavioral (Brzeziński \& Bąk, 2015). The cognitive dimension refers to employees’ knowledge about the organization. The emotional dimension refers to the employee's feelings, goals, 
approach, and attachment to organizational values. The behavioral dimension is the involvement of employees to act on their initiative, even at the expense of their convenience, and treat change as an opportunity. An emotional dimension is a form of affective commitment as a commitment between employees and the organization as well as the shared vision, values, and goals between individuals and the organization (Folorunso et al., 2014; Wulandari \& Putriyanti, 2020).

\section{Employee performance}

In general, the concept of employee performance is conceptualized differently and used in various disciplines. This definition describes the differences from the literature review regarding contextual performance and task performance (Wulandari \& Putriyanti, 2020). The dimensions that are often used to describe individual performance are task performance and contextual performance. Task performance is defined as pro-efficiency performance such as high competence with which a person performs the main work. Other labels used to describe task performance are task-specific, technical understanding of the job, or good understanding of roles. Task performance is also described as the ability of an individual to work in terms of work quantity, work quality, and work knowledge (Freese \& Fay, 2001; Sonnentag, 2002; Van \& LePine, 1998; Wulandari \& Putriyanti, 2020). Employees are the most important resource in the productivity and effectiveness of employee performance in a company. An important role that employees have is to perform tasks to achieve of company goals. The success achieved by employees can be measured after meeting the quality and quantity standards set by working effectively and efficiently (Wulandari \& Putriyanti, 2020).

\section{Hypothesis Development}

\section{The Influence of HRM Practices on Employee Performance}

Kitchot et al., (2020) state that HRM has a strategic role as a mediation that encourages the role of supply chain management on business performance. Without the implementation of HRM in the company, supply chain management cannot improve business performance. In line with the research conducted by Gahlawat \& Kundu, (2019) HRM practices can improve employee performance by mediating organizational climate and affective commitment as well as the desire to leave the organization. This study supports the view of the role of HRM practices in increasing positive work attitudes and encouraging maximum company performance. This is in line with research conducted by Dabale et al., (2014) that shows a positive relationship between training and employee performance. HRM practices can produce benefits for the knowledge, skills, abilities, competencies, and behavior of employees. With these results, this study draws the following hypothesis:

$\mathrm{H}_{1}$ : HRM practices influence employee performance in the public service sectors. 


\section{The Influence of HRM practices on affective commitment and employee performance}

Gahlawat \& Kundu (2019) elaborate on the role of HRM in increasing positive attitudes, one of which is an affective commitment as an important work attitude that explains the emotional attachment between employees and the organization. Employees' awareness of HRM practices of an organization in the form of self-managed teams, work flexibility, and empowerment will be rewarded by employees' high engagement with the organization. In line with this, Cheung \& Wu (2011) state that a positive work attitude shows a harmonious relationship between employees and the organization. Muma et al., (2014) argue that employee commitment is multidimensional in nature, involving employee loyalty to the organization, availability to mobilize energy on behalf of the organization, achieving goals and values that are following the organization, and the desire to maintain membership in the organization. With these results, the following hypotheses are formulated:

$\mathrm{H}_{2}$ : HRM practices influence the affective commitment of employees in public service sectors. $\mathrm{H}_{3}$ : Affective commitment influences employee performance in the public service sectors.

\section{The Influence of job involvement on affective commitment and employee performance}

A study conducted by Septiadi et al., (2017) proves that organizational commitment acts as a mediator on the relationship between job involvement and employee performance. It is reinforced by Singh \& Gupta (2015) that there is an influence of job involvement in the forms of commitment such as professional commitment, team commitment, and organizational commitment. The results show that job involvement increases the relationship with affective and normative commitment but has a negative relationship with continuance commitment, especially in the younger generation who tend to have lower loyalty than the older one. In addition, research by Kooij et al., (2010) showed that high commitment HRM practices related to promotion, job enrichment, and participation were positively related to affective commitment and job satisfaction. Amelia in her research (2016) shows that training, job involvement, and competence simultaneously have a significant influence on employee performance at PT. Bank Sulut Go Manado. With these results, this study formulates the following hypothesis:

$\mathrm{H}_{4}$ : Job involvement influences the affective commitment of employees in the public service sectors.

$\mathrm{H}_{5}$ : Job involvement influences employee performance in the public service sectors.

\section{METHOD}

\section{Population, Sample, and Sampling Technique}

The population in this study were employees who worked in the public service sectors during the COVID-19 pandemic. This study used a sample of 105 respondents of employees in 
the public service sectors. A probability sampling was employed, more precisely, a random sampling method. One of the types of probability sampling is cluster sampling that takes into account the representation of each cluster based on occupation.

Table 1. Distribution of Samples by Occupation

\begin{tabular}{|c|l|c|c|}
\hline No. & \multicolumn{1}{|c|}{ Occupation } & Total & Percentage $(\%)$ \\
\hline 1. & Midwives, nurses, and physicians & 16 & $15.3 \%$ \\
2. & Manager/echelon II & 6 & $5.7 \%$ \\
3. & Teacher & 2 & $1.9 \%$ \\
4. & Policeman & 5 & $4.8 \%$ \\
5. & Flight attendant & 1 & $1.0 \%$ \\
& Staff/ personnel at Regional & 69 & $65.7 \%$ \\
& government/Regional-owned & & \\
7 & enterprises/state-owned enterprises & 2 & $1.9 \%$ \\
8. & Supervisor/ echelon III & 4 & $3.8 \%$ \\
\hline \multicolumn{2}{r|}{ National Military Army } & 105 & $100 \%$ \\
\hline
\end{tabular}

Source: Primary Data, Processed 2021

Table 1 shows 6 respondents (15.3\%) work as midwives, nurses, and doctors, 6 respondents $(5.7 \%)$ work as managers or in echelon III positions, 2 respondents $(1.9 \%)$ work as civil servants, 5 respondents $(4.8 \%)$ work as a policeman, 1 respondent as a flight attendant, and 69 respondents $(65.7 \%)$ work as staff, 2 respondents $(1.9 \%)$ work as a supervisor or echelon III, and 4 respondents work as National Military Army. Thus, it can be concluded that the majority of respondents from this study work as a staff.

\section{Operational Definition of Variables}

The variables in this study are described and measured based on the description in Table 2. :

Table 2. Operational Definition of Variables of the Study

\begin{tabular}{|c|l|l|}
\hline Variable & \multicolumn{1}{|c|}{$\begin{array}{c}\text { Operational Definition of } \\
\text { Variables }\end{array}$} & \multicolumn{1}{c|}{ Indicator } \\
\hline \multirow{3}{*}{$\begin{array}{c}\text { HRM Practices } \\
\text { X1) }\end{array}$} & $\begin{array}{l}\text { 1. Recruitment process, } \\
\text { recruitment, selection and training, } \\
\text { and development to improve } \\
\text { organizational performance. }\end{array}$ & $\begin{array}{l}\text { 3. Awarding } \\
\text { 4. Retaining employees, including } \\
\text { providing allowance, health, and } \\
\text { safety (Kitchot et al., 2020; } \\
\text { Nasurdin et al., 2015) }\end{array}$ \\
\hline Job involvement & Job involvement is how much an \\
X2) & individual identifies with his job & $\begin{array}{l}\text { 1.Mental participation of employee } \\
\text { 2.Emotional participation of } \\
\text { employee }\end{array}$ \\
\hline
\end{tabular}


82 Pamungkas, V. D. \& Wulandari, F., The Influence of Human Resource Management Practices and...

\begin{tabular}{|c|c|c|}
\hline & & $\begin{array}{l}\text { 3. Responsibility } \\
\text { 4. Being active in self-development } \\
\text { 5.Using energy to get the job done } \\
\text { (Panjaitan, 2018; Zhang et al., } \\
\text { 2020) }\end{array}$ \\
\hline $\begin{array}{l}\text { Employee } \\
\text { Performance } \\
\text { (Y) }\end{array}$ & $\begin{array}{l}\text { Employee performance is the result } \\
\text { of an employee's work that has a } \\
\text { direct impact on increasing output }\end{array}$ & $\begin{array}{l}\text { 1. Quality } \\
\text { 2. Quantity } \\
\text { 3. Punctuality } \\
\text { 4. Effectiveness } \\
\text { 5. Working Standard } \\
\text { 6. Contributive Feedback } \\
\text { (Wulandari \& Putriyanti, 2020) }\end{array}$ \\
\hline $\begin{array}{l}\text { Affective } \\
\text { Commitment } \\
\text { (Z) }\end{array}$ & $\begin{array}{l}\text { Affective commitment is the extent } \\
\text { to which an employee has feelings } \\
\text { towards the organization such as the } \\
\text { emotional connection between the } \\
\text { individual and the organization }\end{array}$ & $\begin{array}{l}\text { 1. Strong bond to the organization } \\
\text { 2. Emotional attachment to the } \\
\text { organization } \\
\text { 3. Proud to be part of the } \\
\text { organization } \\
\text { 4. Shared goal with the organization } \\
\text { 5. Shared values with the } \\
\text { organization } \\
\text { 6. Shared vision as the organization } \\
\text { (Anvari et al., 2014; Wulandari } \\
\text { triyanti, 2020) }\end{array}$ \\
\hline
\end{tabular}

\section{Data Analysis}

Data analysis in this study aims to test the research hypotheses proposed. The hypotheses to be tested are the influence of variables as described earlier based on testing the effect. Therefore, in analyzing the data, regression analysis was used employing IBM SPSS for windows version 22.

\section{RESULTS}

\section{Respondent Characteristics based on Age, Experience, and Salary}

Based on the data tabulation from all respondents, the general description of respondents based on age is shown in Table 3.

Table 3. Respondent Characteristics

\begin{tabular}{|c|c|c|c|}
\hline No & Age Interval & Total & Percentage (\%) \\
\hline \multicolumn{4}{|c|}{ Respondent's Age } \\
\hline 1. & $26-30$ years old & 95 & $90.5 \%$ \\
\hline 2. & 31-35 years old & 3 & 2.95 \\
\hline 3. & $36-40$ years old & 1 & $1 \%$ \\
\hline 4. & 41-45 years old & 3 & $2.9 \%$ \\
\hline 5. & $46-50$ years old & 2 & $1.9 \%$ \\
\hline \multirow[t]{2}{*}{6.} & $>50$ years old & 1 & $1 \%$ \\
\hline & Total & 105 & $100 \%$ \\
\hline
\end{tabular}




\begin{tabular}{|c|l|c|c|}
\hline \multicolumn{3}{|c|}{ Work Experience } \\
\hline 1. & $<6$ years old & 90 & $85.7 \%$ \\
2. & 6-10 years old & 7 & $6.7 \%$ \\
3. & 11-15 years old & 3 & $2.9 \%$ \\
4. & 16-20 years old & 1 & $1 \%$ \\
5. & $>$ 20 years old & 4 & $3.8 \%$ \\
\hline \multicolumn{5}{|c|}{ Salary } \\
\hline \multicolumn{5}{|l|}{ Total } & 505 & $100 \%$ \\
\hline 1. & $<3$ & 32 & $47.6 \%$ \\
2. & $3-5$ Million (IDR) & 19 & $30.5 \%$ \\
3. & $6-10$ Million (IDR) & 2 & $18.1 \%$ \\
4. & $11-15$ Million (IDR) & 2 & $1.9 \%$ \\
5. & $>15$ Million (IDR) & 105 & $100 \%$ \\
\hline
\end{tabular}

Table 3 describes respondent's age, experience, and salary. In terms of age, 95 respondents were 26-30 years old (90.5\%), 3 respondents were 31 -35 years old $(2.95 \%), 1$ respondent was 3640 years old (1\%), 3 respondents were 41-45 years old (2.9\%), 2 respondents were 46-50 years old $(1.9 \%)$, and 1 respondents was $>50$ years $(1 \%)$. Thus, it can be concluded that the majority of respondents were aged 26-30 years.

Observing from the experience of respondents. 90 respondents were working for $<6$ years $(85.7 \%), 7$ respondents were working for 6-10 years $(6.7 \%), 3$ respondents were working for 11 15 years (2.9\%), 1 respondent was working for 16-20 years (1\%), and 4 respondents were working for $>20$ years $(3.8 \%)$. Thus, it can be concluded that the majority of respondents work for less than 6 years.

Based on the salary of respondents, 50 respondents had a salary of $<3$ million (47.6\%), 32 respondents had a salary of 3-5 million (30.5\%), 19 respondents had a salary of 6-10 million (18 $.1 \%), 2$ respondents had a salary of $11-15$ million (1.9\%), and 2 respondents had a salary of $>15$ million $(1.9 \%)$. Thus, it can be concluded that the majority of respondents earned less than IDR 3 million.

\section{Validity and Reliability Test}

Table 4. Validity and Reliability

\begin{tabular}{|c|c|c|c|c|}
\hline No. & Item & Outer loadings & Cronbach's Alpha & Conclusion \\
\hline \multicolumn{5}{|l|}{ HRM Practices } \\
\hline 1. & HRM1 & 0.709 & 0.877 & Valid \\
2. & HRM2 & 0.864 & & Valid \\
3. & HRM3 & 0.879 & & Valid \\
4. & HRM4 & 0.850 & & Valid \\
5. & HRM5 & 0.798 & & Valid \\
\hline
\end{tabular}


84 Pamungkas, V. D. \& Wulandari, F., The Influence of Human Resource Management Practices and...

\begin{tabular}{|c|c|c|c|c|}
\hline \multicolumn{5}{|l|}{ Job involvement } \\
\hline 1 & WI1 & 0.936 & 0.942 & Valid \\
2 & WI2 & 0.917 & & Valid \\
3 & WI3 & 0.906 & & Valid \\
4 & WI4 & 0.912 & Valid \\
5 & WI5 & 0.835 & Valid \\
\hline Affective Commitment & & Valid \\
\hline 1 & AC1 & 0.836 & 0.929 & Valid \\
2 & AC2 & 0.913 & & Valid \\
3 & AC3 & 0.825 & & Valid \\
4 & AC4 & 0.887 & & Valid \\
5 & AC5 & 0.847 & & Valid \\
6 & AC6 & 0.867 & & Valid \\
\hline Employee Performance & & & Valid \\
\hline 1 & KK1 & 0.836 & & Valid \\
2 & KK2 & 0.913 & & Valid \\
3 & KK3 & 0.825 & & Valid \\
\hline
\end{tabular}

Based on the results of the validity test for the variable of HRM practices in Table 3, it can be seen that the $r_{\text {count }}>r_{\text {table }}$ (two-tailed with sig. 0.05). Thus, it can be concluded that all questionnaire items in the variable of HRM practice are valid. The $\mathrm{r}_{\text {count }}>\mathrm{r}_{\text {table }}$ (two-tailed with sig. 0.05 ) shows that all questionnaire items od the variable of Job involvement are valid. The value of $\mathrm{r}_{\text {count }}>\mathrm{r}_{\text {table }}$ (2-tailed with sig. 0.05) shows that all questionnaire items in the variable of Employee Performance are valid. The value of $r_{\text {count }}>r_{\text {table }}$ (2-tailed with sig. 0.05$)$ shows that all questionnaire items in the variable of affective commitment are valid. The Cronbach Alpha value of all variables of $>0.7$ shows that all variables used in the study are reliable and can be used as measuring instruments.

\section{Classical assumption test}

The classical assumption test is a requirement that must be met in multiple linear regression analysis. A regression model has a normal distribution if the probability and Kolmogorov-Smirnov $\mathrm{p}>0.05$. The analysis employing the IBM SPSS 22 software shows the p-values are 0.245 and 0.230 where the value of $>0.05$. Thus, it can be concluded that the research data is normally distributed. The multicollinearity test aims to see whether there is a correlation between independent variables in multiple linear regression models. It is usually done using regression analysis by looking at the tolerance and variance inflation factor (VIF). The results show the tolerance value of all variables $>0.1$ and the VIF value $<10$. Thus, it can be concluded that in this 
study, there is no multicollinearity in the regression model. The heteroscedasticity test is a test used to determine whether the regression model has variance (heteroscedasticity) variance from the residuals of one observation with another observation. The results of the heteroscedasticity test show the Sig. of all variables $>0.05$. Thus, it can be concluded that in this study there was no heteroscedasticity.

\section{Path Analysis}

Table 5. Path Analysis Results

\begin{tabular}{|c|c|c|c|c|c|c|}
\hline \multirow[t]{2}{*}{ Independent variables } & \multicolumn{2}{|c|}{$\begin{array}{l}\text { Step } 1 \text { (affective } \\
\text { commitment) }\end{array}$} & \multirow[t]{2}{*}{ Sig. } & \multicolumn{2}{|c|}{$\begin{array}{c}\text { Step } 2 \text { (employee } \\
\text { performance) }\end{array}$} & \multirow[t]{2}{*}{ Sig. } \\
\hline & $\beta$ & $\mathrm{t}$ & & $\beta$ & $\mathrm{t}$ & \\
\hline HRM Practices & .137 & 2.445 & $.016 * *$ & .168 & 2.024 & $.046^{* *}$ \\
\hline Job involvement & .601 & 9.089 & $.000 *$ & .604 & 5.569 & $.000^{*}$ \\
\hline \multirow[t]{2}{*}{ Affective Commitment } & - & - & - & .107 & 2.029 & $.041 * *$ \\
\hline & \multicolumn{3}{|c|}{$\begin{array}{c}\text { R Square }=0.703 \\
\text { Adjusted R Square }=0.709 \\
\mathrm{~F}=124.228^{*}\end{array}$} & \multicolumn{3}{|c|}{$\begin{array}{c}\text { R Square }=0.682 \\
\text { Adjusted R Square }=0.672 \\
\mathrm{~F}=72.154^{*}\end{array}$} \\
\hline
\end{tabular}

$\mathrm{p}^{* *}<.05, \mathrm{p}^{*}<.01$

The first path analysis shows that there is a positive and significant influence of HRM practices on affective commitment. Likewise, there is a positive and significant influence between job involvement and affective commitment. Job involvement has a greater influence in increasing affective commitment. In the second path analysis, the results show that there is a positive and significant influence between HRM practices on employee performance. The influence of job involvement on employee performance shows positive and significant results. The influence of affective commitment on employee performance also shows significant positive results

\section{Sobel Test}

Table 6. The Mediation of Affective Commitment

\begin{tabular}{|llcccl|}
\hline $\begin{array}{l}\text { N } \\
\text { o }\end{array}$ & Mediating Variable & $\begin{array}{l}\text { Sobel test } \\
\text { statistic }\end{array}$ & $\begin{array}{l}\text { One-tailed } \\
\text { probability }\end{array}$ & $\begin{array}{l}\text { Two-tailed } \\
\text { probability }\end{array}$ & Result \\
\hline 1 & $\begin{array}{l}\text { Practice HRM } \rightarrow \text { Affective } \\
\text { Commitment } \rightarrow \text { Employee } \\
\text { Performance }\end{array}$ & 0.94883430 & 0.17135245 & 0.34270490 & Mediation \\
2 & $\begin{array}{l}\text { Job Involvement } \rightarrow \text { Affective } \\
\text { Commitment } \rightarrow \text { Employee } \\
\text { Performance }\end{array}$ & 1.02289641 & 0.15317841 & 0.30635683 & No \\
\hline
\end{tabular}


86 Pamungkas, V. D. \& Wulandari, F., The Influence of Human Resource Management Practices and...

The results of data analysis showed that affective commitment was not able to mediate the effect of HRM practices on employee performance. The results also explain that affective commitment also fails to mediate the influence of job involvement on employee performance.

\section{DISCUSSION}

HRM practices have a positive and significant influence (constant 0.160) on employee performance. It is proven from the value of $t_{\text {count }}$ of 2.024 that is greater than $t_{\text {table, }}$ of 1.66008 with of Sig. value of $0.046<0.05$. Thus, it can be concluded that $\mathrm{H}_{0}$ is rejected and $\mathrm{H}_{1}$ is accepted. It is concluded that there is an influence of HRM practices on employee performance in the public service sectors. This means that a series of HRM practices provided by first-line managers to employees can affect employee performance. The more effective the HRM practices provided by first-line managers and the company, the higher the level of productivity of employees. The results of this study are in line with research conducted by (Delery \& Gupta, 2016; Diaz-Fernandez et al., 2017; Moideenkutty et al., 2011) that HRM practices have an effect on increasing employee productivity.

HRM practices have a positive (constant 0.137) and significant influence on affective commitment. It is proven from the value of $t_{\text {count }}$ of 2.445 which is greater than $t_{\text {table }}$ of 1.66008 with a Sig value. of $0.016<0.05$. Thus, it can be concluded that $\mathrm{H}_{0}$ is rejected and $\mathrm{H}_{2}$ is accepted, There is an influence of HRM practices on the affective commitment of employees in the public service sectors. In carrying out effective HRM practices, it requires good cooperation between first-line managers and the organization so that HRM practices can be well received by employees. In addition, by providing high and maximum service quality to employees, it can increase employees' affective commitment. The results of this study are in line with research conducted by Gahlawat \& Kundu (2019) that first-line managers can increase employee affective commitment by implementing effective HR practices.

Job involvement has a positive (constant 0.601) and significant effect on affective commitment as proven by the value of $t_{\text {count }}$ of 9.089 that is greater than $t_{\text {table }}$ of 1.66008 with a Sig value. of $0.000<0.05$. Thus, it can be concluded that $\mathrm{H}_{0}$ is rejected and $\mathrm{H}_{3}$ is accepted, then there is an influence between job involvement on the affective commitment of employees in the public service sectors. Involvement can affect affective commitment since employees are always involved in all organizational affairs both inside and outside the organization. It can foster an emotional sense both physically and non-physically towards the company. By being involved, employees will have the ability to transfer all their abilities to the organization through affective commitment. The 
results of this study are in line with research conducted by Singh \& Gupta, (2015) that job involvement can increase employee affective commitment.

Job involvement has a positive (constant 0.681) and significant influence on employee performance. It can be seen from the value of $t_{\text {count }}$ of 5.569 that is greater $t_{\text {table }}$ of 1.66008 with a Sig value. of $0.000<0.05$. Thus, it can be concluded that $\mathrm{H}_{0}$ is rejected and $\mathrm{H}_{4}$ is accepted. Thus, there is an influence of job involvement on employee performance owned by employees in the public service sectors. Job involvement is a positive thing that encourages a person to feel that work is the most important thing for him. In its application, job involvement can affect the performance of the employee because by being involved, someone will be optimal and maximal in completing his work. The results of this study are in line with research conducted by Septiadi et al., (2017) that job involvement has a positive influence on employee performance.

Affective commitment has a positive (constant 0.140) and significant influence on employee performance. It is known based on the value of $t_{\text {count }}$ of 2.029 that is greater than the $t_{\text {table }}$ of 1.66008 with a value of Sig. of $0.041<0.05$. Thus, it can be concluded that $\mathrm{H}_{0}$ is rejected and $\mathrm{H}_{5}$ is accepted. There is an influence of affective commitment on employee performance owned by employees in the public service sectors. Someone who has the same values and goals with the organization will stay in the company. In addition, they will do everything to help achieve the company's goals. If someone has been involved in achieving company goals, it can be ascertained that he has a high affective commitment to the organization. In addition, if a person has a good affective commitment to the organization, it is certain that his performance for the company will be optimum. The results of this study are in line with research conducted by Muma et al., (2014) and Şendoğdu et al., (2013) that there is a positive and significant influence of affective commitment on employee performance.

\section{CONCLUSION AND SUGGESTION}

This study aims to determine the influence of HRM practices and job involvement on employee performance in the public service sectors mediated by affective commitment during the covid-19 pandemic. All results show a positive and significant influence. However, the second mediating role failed to show the relationships. Further research is recommended to take more samples and different settings (places/locations/objects) to give different results. The role of job involvement is the most dominant in encouraging affective commitment and employee performance. Organizations need to adopt policies that encourage more employee participation, flexibility in working, and psychological empowering to increase effectiveness, efficiency, quality, quantity, and constructive inputs that are beneficial to the organization. 


\section{REFERENCES}

Anvari, R., Mansor, N. N. A., Rahman, S. A. B. P. A., Rahman, R. H. B. A., \& Chermahini, S. H. (2014). Mediating effects of affective organizational commitment and psychological contract in the relationship between strategic compensation practices and knowledge sharing. Procedia - Social and Behavioral Sciences, 129, 111-118.

Brzeziński, S., \& Bakk, A. (2015). Management of employees' commitment in the process of organization transformation. Procedia Economics and Finance, 27(15), 109-115.

Dabale, W. P., Jagero, N., \& Nyauchi, M. (2014). The Relationship between Training and Employee Performance: The Case of Mutare City Council, Zimbabwe. International Journal of Human Resource Studies, 4(4), 61. https://doi.org/10.5296/ijhrs.v4i4.6620

Delery, J., \& Gupta, N. (2016). Human resource management practices and organizational effectiveness: internal fit matters. Journal of Organizational Effectiveness, 3(2), 139-163. https://doi.org/10.1108/JOEPP-03-2016-0028

Diaz-Fernandez, M., Bornay-Barrachina, M., \& Lopez-Cabrales, A. (2017). HRM practices and innovation performance: a panel-data approach. International Journal of Manpower, 38(3), 354372. https://doi.org/10.1108/IJM-02-2015-0028

Folorunso, O. O., Adewale, A. J., \& Abodunde, S. M. (2014). Exploring the Effect of Organizational Commitment Dimensions on Employees Performance: An Empirical Evidence from Academic Staff of Oyo State Owned Tertiary Institutions, Nigeria. International Journal of Academic Research in Business and Social Sciences, 4(8), 275.

Freese, M., \& Fay, D. (2001). Personal initiative (PI): An active performance concept for work in the 21st century. Research in Organizational Behavior, 23, 133-187.

Gahlawat, N., \& Kundu, S. C. (2019). Participatory HRM and firm performance: Unlocking the box through organizational climate and employee outcomes. Employee Relations, 41(5), 10981119. https://doi.org/10.1108/ER-05-2018-0147

Hermawati, A., \& Mas, N. (2017). Mediation effect of quality of worklife, job involvement, and organizational citizenship behavior in relationship between transglobal leadership to employee performance. International Journal of Law and Management, 59(6), 1143-1158. https://doi.org/10.1108/IJLMA-08-2016-0070

Kamuri, K. J. (2017). Electronic Human Resource Management: inovasi pengelolaan sumber daya manusia dalam organisasi (analisis penerapan e-HRM pada PT Telkom wilayah KupangNTT). Journal of Management, 4(1), 33-52.

Kitchot, S., Siengthai, S., \& Sukhotu, V. (2020). The mediating effects of HRM practices on the relationship between SCM and SMEs firm performance in Thailand. Supply Chain Management, 26(1), 87-101. https://doi.org/10.1108/SCM-05-2019-0177

Mardatillah, Y., Nasution, H., \& Ishak, A. (2013). Evaluasi kinerja manajemen sumber daya manusia PT. Bank XYZ dengan human resource scorecard. Jurnal Teknik Industri USU, 1(1), $23-27$. 
Memon, M. A., Salleh, R., Mirza, M. Z., Cheah, J. H., Ting, H., Ahmad, M. S., \& Tariq, A. (2020). Satisfaction matters: the relationships between HRM practices, work engagement and turnover intention. International Journal of Manpower, 42(1), 21-50. https://doi.org/10.1108/IJM-04-2018-0127

Moideenkutty, U., Al-Lamki, A., \& Murthy, Y. S. R. (2011). HRM practices and organizational performance in Oman. Personnel Review, 40(2), 239-251. https://doi.org/10.1108/00483481111106101

Muma, M., Iravo, D. A., \& Omondi, D. M. (2014). Effect of training needs assessment on employee commitment in public Universities: A case study of Jomo Kenyatta University of Agriculture and Technology. International Journal of Academic Research in Business and Social Sciences, 4(9), 233-250. https://doi.org/10.6007/ijarbss/v4-i9/1153

Nasurdin, A. M., Ahmad, N. H., \& Tan Cheng Ling. (2015). High performance human resource practices, identification with organizational values and goals, and service-oriented organizational citizenship behavior: a review of literature and proposed model. SHS Webof Conferences, 1-15.

$\mathrm{f} \backslash$ Ovt,cen, E., Francis, K., \& Angundaru, G. (2017). The role of training in building employee commitment: the mediating effect of job satisfaction. European Journal of Training and Development, 41(9), 742-757. https://doi.org/10.1108/EJTD-11-2016-0084

Panjaitan, M. (2018). Peran keterlibatan dan partisipasi karyawan terhadap kinerja karyawan. Jurnal Manajemen, 4(1), 52-60.

Paolillo, A., Platania, S., Magnano, P., \& Ramaci, T. (2015). Organizational Justice, Optimism and Commitment to Change. Procedia - Social and Behavioral Sciences, 191, 1697-1701. https://doi.org/10.1016/j.sbspro.2015.04.479

Rotenberry, P. F., \& Moberg, P. J. (2007). Assessing the impact of job involvement on performance. Management Research News, 30(3), 203-215. https://doi.org/10.1108/01409170710733278

Şendoğdu, A. A., Kocabacak, A., \& Güven, Ş. (2013). The Relationship between Human Resource Management Practices and Organizational Commitment: A Field Study. Procedia - Social and Behavioral Sciences, 99, 818-827. https://doi.org/10.1016/j.sbspro.2013.10.553

Sonnentag, S. (2002). Performance Concepts and Performance Theory. Psychological Management of Individual Performance., 23(1), 3-25.

Tri Wikaningrum. (2011). Praktek dan Kebijakan Manajemen Sumber Daya Manusia Pada Perbankan Syariah. Jurnal Siasat Bisnis, 15(1), 99-123.

Van, D. L., \& LePine, J. A. (1998). Helping and voice extra-role behaviors: Evidence of construct and predictive validity. Academy of Management Journal, 41(1), 108-119.

Wulandari, F., Ferdinand, A. T., \& Dwiatmadja, C. (2018). Knowledge sharing in a critical moment of work: A driver for success? International Journal of Knowledge Management, 14(2), 88-98. https://doi.org/10.4018/IJKM.2018040106

Wulandari, F., \& Putriyanti, O. A. (2020). Studi share leadership dan perannya dalam meningkatkan 
90 Pamungkas, V. D. \& Wulandari, F., The Influence of Human Resource Management Practices and...

kinerja karyawan. Jurnal Bisnis Dan Manajemen, 7(2), 74-84. http://jurnal.unmer.ac.id/index.php/jbm/article/view/4076

Zhang, F., Zhu, L., \& Wei, L. (2020). Shareholder involvement and firm innovation performance: Empirical evidence from Chinese firms. Chinese Management Studies, 14(3), 833-855. https://doi.org/10.1108/CMS-01-2019-0029 